\title{
Australia: Information Note on Fiscal Data
}

This Information Note on Australia's Fiscal Data was prepared by a staff team of the International Monetary Fund as background documentation for the periodic consultation with the member country. It is based on the information available at the time it was completed on September 13, 2006. The views expressed in this document are those of the staff team and do not necessarily reflect the views of the government of Australia or the Executive Board of the IMF.

The policy of publication of staff reports and other documents by the IMF allows for the deletion of market-sensitive information.

To assist the IMF in evaluating the publication policy, reader comments are invited and may be sent by e-mail to publicationpolicy@imf.org.

Copies of this report are available to the public from

International Monetary Fund • Publication Services

700 19th Street, N.W. • Washington, D.C. 20431

Telephone: (202) 6237430 • Telefax: (202) 6237201

E-mail: publications@imf.org • Internet: http://www.imf.org

\section{International Monetary Fund Washington, D.C.}





\title{
INTERNATIONAL MONETARY FUND
}

\author{
Information Note on Australia's Fiscal Data
}

Prepared by the Statistics Department

Approved by the Statistics, Fiscal Affairs, and Asia and Pacific Departments

September 13, 2006

Contents

Page

I. Presentation of Australia's Fiscal Data Using the Framework of the GFSM 2001, Preliminary Results

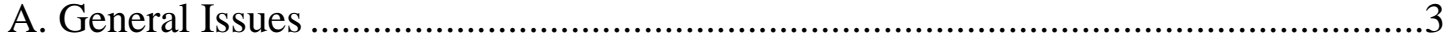

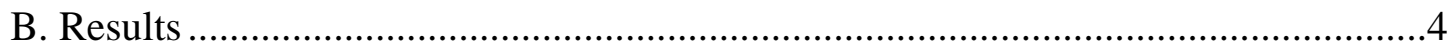

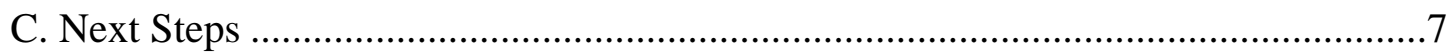

Tables

1. Australia: Statement of General Government Operations ..........................................

2. Australia: Integrated Balance Sheet for the General Government...................................9

3. Australia: Statement of Sources and Uses of Cash for the General Government...............10

\section{Boxes}

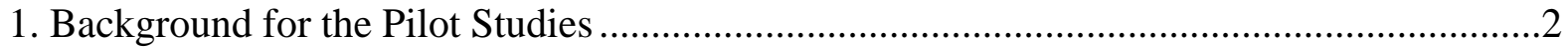

2. The GFSM 2001 Statements and Core Balances.............................................................6 


\section{Presentation of Australia's Fiscal Data Using the Framework of the GFSM 2001, PRELIMINARY RESUlTS}

1. At the Executive Board seminar on November 16, 2005 Directors agreed that the use of the Government Finance Statistics Manual (GFSM 2001) framework would lead to greater transparency and consistency in the presentation of country fiscal data in staff reports (See Box 1 for background). This paper reports on the preliminary results for Australia of the pilot study which sets out to incorporate the GFSM 2001 operating statement, integrated balance sheet, and cash statement in the Article IV consultation. ${ }^{1}$ First, there is a discussion of the data sources and the institutional coverage used in the Australian pilot. Then, some preliminary statistical data that are drawn from the national data sources are presented. Finally, there is a discussion of future work to refine detailed components of the data presented.

2. The paper concludes that since the Australian authorities compile fiscal statistics that closely follow the GFSM 2001 principles, the main fiscal aggregates for general government derived from this framework do not significantly differ from those shown in the Article IV staff report. However, the presentational format of the fiscal data proposed in GFSM 2001 tables highlights a number of issues that are important for fiscal analysis, such as the composition of revenue and expense of the general government, the structure of its balance sheet, and determinants of the change in net worth.

\section{Box 1. Background for the Pilot Studies}

The Executive Board seminar on November 16, 2005 discussed the joint STA/FAD paper "Using the GFSM 2001 Statistical Framework to Strengthen Fiscal Analysis in the Fund" (http://www.imf.org/external/np/pp/eng/2005/102505.pdf). Directors noted that use of the GFSM 2001 framework will lead to greater transparency and consistency in the presentation of country fiscal data in staff reports and agreed on the following:*

- $\quad$ In principle, that the Fund should move in a phased way to present fiscal data using the GFSM 2001 framework in staff reports.

- $\quad$ To conduct pilot studies to include the GFSM 2001 operating statement, integrated balance sheets, and cash statements in Article IV consultation reports. The pilot studies should be done for volunteer countries, over the course of two years and within the Fund's budgetary envelope, to map out more fully the process involved in moving to the GFSM 2001 framework.

- $\quad$ That the staff should report to the Board on the experience with the pilot studies, together with migration path proposals to fully implement the GFSM 2001 methodology.

* For a more complete summary of the discussion, see the Public Information Notice (PIN) No. 05/167 available online at http:/www.imf.org/external/np/sec/pn/2005/pn05167.htm.

\footnotetext{
${ }^{1}$ The omission of the GFSM 2001 tables from the staff report for the 2006 Article IV consultation with Australia (http://www.imf.org) largely reflects the later starting point of work on constructing and crosschecking these tables for Australia.
} 


\section{A. General Issues}

3. The Australia pilot study is considered a point of reference for other pilot studies which set out to implement the GFSM 2001 framework as a means of strengthening fiscal analysis within the Fund. Australia was selected as a pilot study by Fund staff in consultation with the national authorities in recognition of the progress that the Australian and state governments have made in compiling and disseminating fiscal statistics on an accrual basis which closely follow the principles of the GFSM 2001.

4. The data sources used for the pilot study are the statistics compiled and disseminated by the Australian Bureau of Statistics (ABS). The tables include data from $1999 / 00$ to 2004/05 and are the same as those provided by the ABS for publication in the 2006 edition of the IMF's Government Finance Statistics Yearbook (GFSY).

5. The institutional coverage in this pilot study is the general government. The tables present a complete set of fiscal data for the general government sector (i.e., consolidated data for the commonwealth, state, and local governments).Article IV staff reports for Australia have focused on central government issues, while taking into account developments in fiscal balances at broader levels of government. Indeed, the reports present aggregated fiscal balance data up to the nonfinancial public sector. Nonetheless, state and local governments in Australia undertake significant revenue, expense, and investment functions in their own right, which can have an impact on aggregate demand and on financial resources that are available for private sector activities. ${ }^{2}$ Hence, tables providing more comprehensive information on fiscal operations with a broader institutional coverage, such as general government, are likely to contribute to enhanced fiscal analysis in the future.

6. The development over time of transactions undertaken by central government may differ considerably from the performance of other levels of government. To give an example drawn from the Australian case, interest paid by central government went down from 1.6 percent of GDP in 1999/00 to nearly 1.0 percent of GDP in 2004/05, a reduction of 37 percent. The corresponding numbers

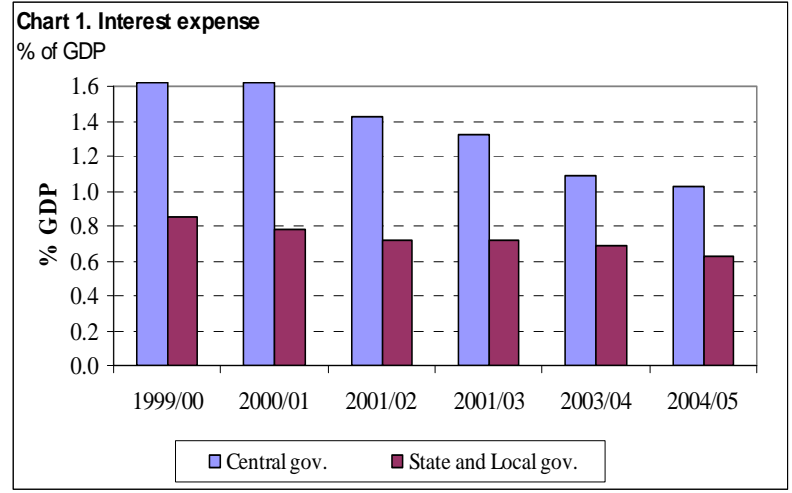
for state and local government were 0.8 percent of GDP and nearly 0.6 percent of GDP, implying a reduction of 26 percent (see Chart 1). This outcome reflects the Commonwealth's successful effort of bringing down its outstanding interest-bearing liabilities during the

\footnotetext{
${ }^{2}$ As mentioned in Box 3 of "Achieving Structural Reform in a Federal System" which is available at http://www.imf.org.
} 
considered period. The example illustrates that limiting fiscal analysis to developments in one sector of general government risks drawing incomplete conclusions for government as a whole.

\section{B. Results}

\section{The following paragraphs show, by way of a number of examples, the} advantages of using the GFSM 2001 framework for fiscal analysis for Australia. The GFSM 2001 tables (Tables 1, 2, and 3) are shown in Attachment 1. Box 2 provides a description of the main aggregates and balances of analytical significance used in these tables. Some data gaps at the detailed level remain, but these do not affect the main aggregates and balances.

\section{The general government registered strong financial performance during the} period under review. There was an increase in net worth due to transactions, as measured by the net operating balance (NOB), which was indicative of the sustainability of fiscal policies throughout the period. With the exception of 2001/02, net lending/borrowing (NLB) was also positive during the years reviewed, as the general government's savings exceeded the net investment in nonfinancial assets. These resources enabled general government to reduce its net liabilities and, to a lesser extent, to acquire financial assets on a net basis. Furthermore, the balance sheet shows that the increase in general government's net worth during the period was more pronounced than indicated by transactions. This was brought about by revaluations and other volume changes. Overall, the net financial worth (financial assets minus liabilities) improved from a negative position of 4.2 percent of GDP at the beginning of the period to a positive position of 5.1 percent of GDP in 2004/05. The strength of this fiscal performance was mirrored in the general government's cash operations, where significant cash surpluses were recorded throughout the period.

9. Table 1, the Statement of General Government Operations, shows the transactions of the government on an accrual basis. Two important balances can be derived from this table. The NOB is a key indicator of the ongoing sustainability of government operations, while NLB captures the extent to which the government is either putting financial resources at the disposal of other sectors of the economy or utilizing the financial resources generated by other sectors. ${ }^{3}$ The NLB can be viewed as an indicator of the financial impact of government activity on the rest of the economy.

\footnotetext{
${ }^{3}$ GFS accrual concepts of net operating balance and net acquisitions of nonfinancial assets can be considered as rough approximations of System of National Accounts 1993 concepts of government saving and investment respectively. This conclusion does not hold for the traditional cash-based presentations used in most country staff reports.
} 


\section{Box 2. The GFSM 2001 Statements and Core Balances}

The Statement of government operations (presented in Table 1) records transactions on an accrual basis. The statement distinguishes between the following transactions:

Revenue

Transactions that increase net worth.

Expense

Transactions that reduce net worth.

Net acquisitions of

Transactions that affect the stock of nonfinancial assets, without

nonfinancial assets

changing net worth (acquisitions minus disposals).

Financing

Transactions that affect the stock of financial assets and liabilities, without changing net worth (net acquisition of financial assets minus net incurrence of liabilities).

The analysis of government operations is supported by two key fiscal indicators:

Operating balance

Summary measure of the effects of revenue and expense transactions on net worth. Net operating balance (NOB) equals revenue minus expense. The gross operating balance (GOB) equals revenue minus expense other than consumption of fixed capital. 1/

Net lending/borrowing

Represents the financial resources that the government absorbs from, or releases to, other sectors of the economy. It is calculated as the NOB minus the net acquisition of nonfinancial assets. Net lending/borrowing is also equal to the net acquisition of financial assets minus net incurrence of liabilities.

The Integrated balance sheet (presented in Table 2), focuses on an assessment of the sustainability of government operations from a fiscal perspective. It shows the government's net worth at the beginning and end of each fiscal year, as well as the related transactions and other economic flows. The sustainability of fiscal policy depends in part on how the government's net worth changes over time. Changes in net worth can be explained not only by government's transactions but also by other economic flows attributable to gains or losses resulting from changes in the prices of assets and liabilities, as well as other changes in their volume.

Net worth

The total stock of assets minus liabilities. The net worth in period ( $\mathrm{t}$ ) can also be calculated as the net worth of the previous period (t-1), plus changes in net worth in period ( $t$ ) due to transactions (the NOB), plus changes in net worth in period $(\mathrm{t})$ due to other economic flows.

Net financial worth

The stock of financial assets minus liabilities.

The Statement of sources and uses of cash (presented in Table 3) shows purely cash flows associated with revenue and expense transactions and transactions in nonfinancial assets, which yields the cash surplus/deficit. The assessment of the government's level of cash holdings and its determinants is a key element in analyzing fiscal policy, its interrelationships with the monetary policy and liquidity analysis.

Cash surplus/deficit

Net cash inflow from operating activities minus the net cash outflow from investments in nonfinancial assets.

1/ The NOB/GOB excludes net acquisition of nonfinancial assets. The latter does not affect net worth because it represents only an accumulation of assets in exchange for an accumulation of liabilities or use of existing assets. 
10. Table 2, the integrated

balance sheet, shows that the general government net worth increased throughout the period 2000/01-2004/05 as a result of changes in revenue and expense transactions and, notably, of other economic flows that affect nonfinancial and financial assets.

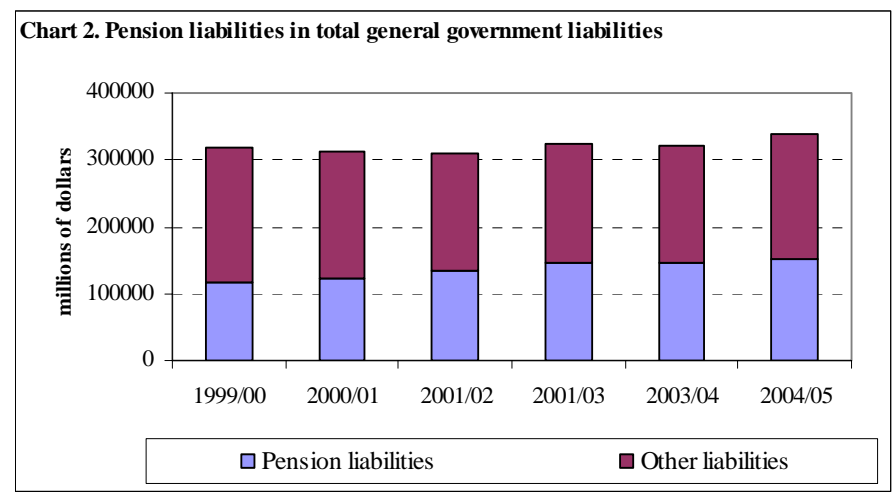

11. The balance sheet allows an important insight into the composition of government liabilities. In 2004/05, liabilities related to unfunded government employee pension funds and other employee entitlements are the largest single category among general government liabilities (see Chart 2). These liabilities rose from 36.3 percent of total liabilities in 1999/00 to 45.2 percent in 2004/05. Obligations of this kind are not recorded in a cashbased system. In contrast, the GFSM 2001 balance sheets recognize governments' present liabilities for future pension obligations that have accrued to-date. ${ }^{4}$

12. Table 3, the Statement of Sources and Uses of Cash, shows purely cash flows associated with revenue and expense transactions and transactions in nonfinancial assets, which together yield the cash surplus/deficit. The data show that the general government generated a cash surplus throughout the period. The analysis of cash data might suggest a greater margin of comfort in fiscal operations than the comparable accrual aggregate, net lending/borrowing, which is shown in the statement of government operations (Table 1).

\section{Countries that base their} fiscal analysis exclusively on cash or accrual data may receive inaccurate signals with regard to their overall fiscal balance. For countries like Australia, where no particular cash constraints exist, one would not expect to see important differences between Table 3 and Table 1 on account of arrears. In

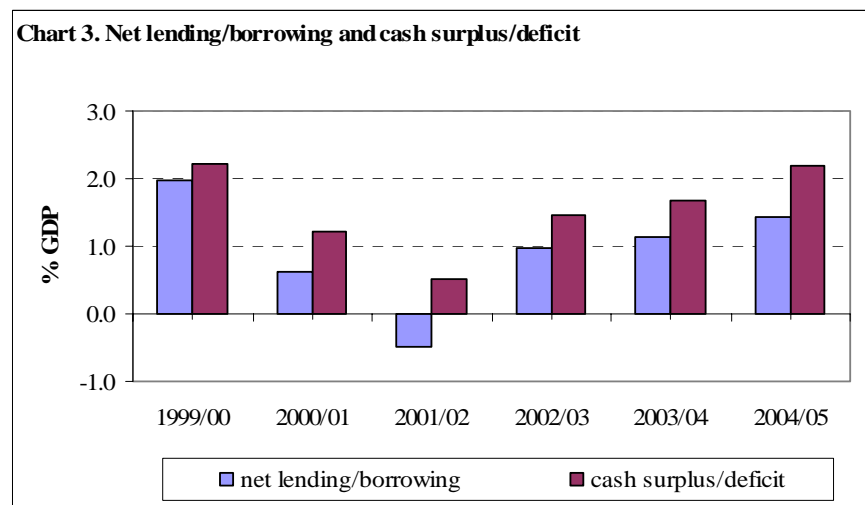
Australia, the accrual aggregate net lending/borrowing is less than the cash surplus/deficit in every year during 1999/00-2004/05 (see Chart 3). The difference between the two measures

\footnotetext{
${ }^{4}$ Following the GFSM 2001 methodology these obligations are recorded in the table as "insurance technical reserves."
} 
is a result of (i) timing differences in the recording of revenue and expenses, which are reflected in accounts payable and receivable, and (ii) the accrual data including expense items which do not have a cash equivalent. The latter item includes the imputed accruing liabilities for the unfunded government employee pension obligations during the period.

14. It should be noted that the overall GFSM 2001 framework provides a tool to check data consistency by integrating stocks and flows. Changes in the balance sheet positions should be fully explained by transactions (presented in Table 1) and other economic flows. These other economic flows are the result of "holding gains/losses" and "other changes in volume." In the case of Australia, a significant portion of the changes in net worth is the result of other economic flows. The ABS has published some information for the central government, which indicates that other economic flows have been affected by large revaluations of nonfinancial assets and the sensitivity of pension liabilities to key parameter assumptions such as the discount rate. Although no data are available, it is likely that the factors observed at the central government level also operate for the state and local governments.

\section{Next Steps}

15. Tables 1, 2, and 3 contain all major aggregates and balances that are essential for fiscal analysis. Staff will continue to work with the authorities to refine the detailed components of these data in the following areas:

- Other economic flows (Table 2. Integrated Balance Sheet for the General Government). Staff will be working with the ABS to expand the range of data available on other economic flows.

- $\quad$ Cash payments for operating activities by economic classification (Table 3. Statement of Sources and Uses of Cash for the General Government). The ABS disseminates the cash flow statement for all subsectors of general government with a classification similar to that prescribed by the GFSM 2001. The ABS has provided a bridge between its classification and the GFSM 2001 classification structure. It is envisaged to construct a more comprehensive bridge that will allow for the production of the full detailed set of accounts set out in Table 3 .

16. It is envisaged that GFSM 2001 data for the general government will be included in subsequent Article IV consultation staff reports for Australia. 
Attachment I

Table 1. Australia: Statement of General Government Operations (GFSM 2001) (In million dollars)

\begin{tabular}{|c|c|c|c|c|c|c|c|}
\hline $\begin{array}{l}\text { GFS } \\
\text { code: }\end{array}$ & GFS Descriptor & 1999/00 & $2000 / 01$ & 2001/02 & 2002/03 & 2003/04 & 2004/05 \\
\hline \multicolumn{8}{|c|}{ Transactions affecting net worth: } \\
\hline 1 & Revenue & 243,119 & 257,103 & 263,085 & 286,843 & 310,936 & 335,668 \\
\hline 11 & Taxes & 196,782 & 214,358 & 217,642 & 238,189 & 257,350 & 278,517 \\
\hline 12 & Social contributions & 0 & 0 & 0 & 0 & 0 & 0 \\
\hline 13 & Grants & 0 & 0 & 1 & 11 & 6 & 10 \\
\hline 14 & Other revenue & 46,337 & 42,745 & 45,442 & 48,643 & 53,580 & 57,141 \\
\hline 2 & Expense & 226,980 & 249,583 & 262,850 & 275,235 & 295,239 & 316,262 \\
\hline 21 & Compensation of employees & 61,058 & 65,117 & 69,377 & 75,221 & 80,735 & 86,247 \\
\hline 22 & Use of goods and services & 43,459 & 47,707 & 50,374 & 53,281 & 56,596 & 60,206 \\
\hline 23 & Consumption of fixed capital & 10,421 & 10,494 & 11,381 & 11,960 & 12,210 & 13,231 \\
\hline 24 & Interest & 15,907 & 16,526 & 15,762 & 15,921 & 14,878 & 14,842 \\
\hline 25 & Subsidies & 6,660 & 8,696 & 9,530 & 10,243 & 11,328 & 12,525 \\
\hline 26 & Grants & 268 & 0 & 0 & 1,884 & 1,445 & 2,333 \\
\hline 27 & Social benefits & 70,252 & 77,885 & 81,695 & 84,280 & 94,096 & 99,260 \\
\hline 28 & Other expense & 18,955 & 23,158 & 24,731 & 22,445 & 23,951 & 27,618 \\
\hline \multicolumn{2}{|c|}{ Net operating balance 1/ } & 16,139 & 7,520 & 235 & 11,608 & 15,697 & 19,406 \\
\hline
\end{tabular}

Transactions in nonfinancial assets

\begin{tabular}{|c|c|c|c|c|c|c|c|}
\hline 31 & Net acquisition of nonfinancial assets $2 /$ & 2,460 & 2,962 & 4,134 & 3,354 & 5,470 & 5,752 \\
\hline 311 & Fixed assets & 4,160 & 3,310 & 4,090 & 4,467 & 4,399 & 5,308 \\
\hline 312 & Change in inventories & -19 & 999 & 157 & -444 & 788 & 507 \\
\hline 313 & Valuables & -22 & 12 & 18 & 5 & -43 & 8 \\
\hline 314 & Nonproduced assets & $-1,659$ & $-1,359$ & -131 & -674 & 326 & -71 \\
\hline \multicolumn{2}{|c|}{ Net lending/borrowing 3/ } & 13,679 & 4,558 & $-3,899$ & 8,254 & 10,227 & 13,654 \\
\hline \multicolumn{2}{|c|}{ Transactions in financial assets and liabilities (financing): } & 13,678 & 4,558 & $-3,899$ & $\mathbf{8 , 2 5 2}$ & 10,227 & 13,657 \\
\hline 32 & Net acquisition of financial assets & 2,927 & $-2,682$ & $-1,285$ & 6,062 & 9,317 & 20,563 \\
\hline 3202 & Currency and deposits & $\ldots$ & $\ldots$ & $\ldots$ & 1,955 & 1,327 & 1,259 \\
\hline 3203 & Securities other than shares & $\ldots$ & $\ldots$ & $\ldots$ & 3,119 & 7,317 & 18,376 \\
\hline 3204 & Loans & $\ldots$ & $\ldots$ & $\ldots$ & 0 & 0 & 0 \\
\hline 3205 & Shares and other equity & $\ldots$ & $\ldots$ & $\ldots$ & 806 & 608 & 884 \\
\hline 3206 & Insurance technical reserves & $\ldots$ & $\ldots$ & $\ldots$ & 0 & 0 & 0 \\
\hline 3207 & Financial derivatives & $\ldots$ & $\ldots$ & $\ldots$ & 0 & 0 & 0 \\
\hline 3208 & Other accounts receivable & $\ldots$ & $\ldots$ & $\ldots$ & 182 & 65 & 44 \\
\hline 33 & Net incurrence of liabilities & $-10,751$ & $-7,240$ & 2,614 & $-2,190$ & -910 & 6,906 \\
\hline 3302 & Currency and deposits & $\ldots$ & $\ldots$ & $\ldots$ & 85 & 143 & 56 \\
\hline 3303 & Securities other than shares & $\ldots$ & $\ldots$ & $\ldots$ & $-7,889$ & $-3,942$ & 63 \\
\hline 3304 & Loans & $\ldots$ & $\ldots$ & $\ldots$ & 0 & 0 & 0 \\
\hline 3305 & Shares and other equity & $\ldots$ & $\ldots$ & $\ldots$ & 0 & 0 & 0 \\
\hline 3306 & Insurance technical reserves & $\ldots$ & $\ldots$ & $\ldots$ & 4,336 & 4,535 & 4,844 \\
\hline 3307 & Financial derivatives & $\ldots$ & $\ldots$ & $\ldots$ & 0 & 0 & 0 \\
\hline 3308 & Other accounts payable & $\ldots$ & $\ldots$ & $\ldots$ & 1,278 & $-1,646$ & 1,943 \\
\hline
\end{tabular}

(In percent of GDP)

\begin{tabular}{|c|c|c|c|c|c|c|c|}
\hline 1 & Revenue & 37.7 & 37.3 & 35.8 & 36.6 & 37.1 & 37.5 \\
\hline 2 & Expense & 35.2 & 36.2 & 35.7 & 35.2 & 35.2 & 35.3 \\
\hline \multicolumn{2}{|c|}{ Net operating balance 1/ } & 2.5 & 1.1 & 0.0 & 1.5 & 1.9 & 2.2 \\
\hline \multicolumn{2}{|c|}{ Primary net operating balance 1/ } & 5.0 & 3.5 & 2.2 & 3.5 & 3.6 & 3.8 \\
\hline 31 & Net acquisition of nonfinancial assets $2 /$ & 0.4 & 0.4 & 0.6 & 0.4 & 0.7 & 0.6 \\
\hline \multicolumn{2}{|c|}{ Net lending/borrowing 3/ } & 2.1 & 0.7 & -0.5 & 1.1 & 1.2 & 1.5 \\
\hline 32 & Net acquisition of financial assets & 0.5 & -0.4 & -0.2 & 0.8 & 1.1 & 2.3 \\
\hline 33 & Net incurrence of liabilities & -1.7 & -1.1 & 0.4 & -0.3 & -0.1 & 0.8 \\
\hline \multicolumn{8}{|c|}{ Memorandum items: } \\
\hline & GDP at market prices (millions of dollars) & 645,153 & 689,340 & 735,783 & 782,798 & 838,251 & 894,665 \\
\hline
\end{tabular}

Sources: ABS official submission for publication in the GFSY.

1/ The net operating balance equals revenue minus expense, where expense includes the consumption of fixed capital.

The gross operating balance equals revenue minus expense other than consumption of fixed capital.

2/ Acquisitions minus disposals and consumption of fixed capital.

3/ Net lending/borrowing equals the net operating balance minus the net acquisition of nonfinancial assets.

It is also equal to the net acquisition of financial assets minus the net incurrence of liabilities. 


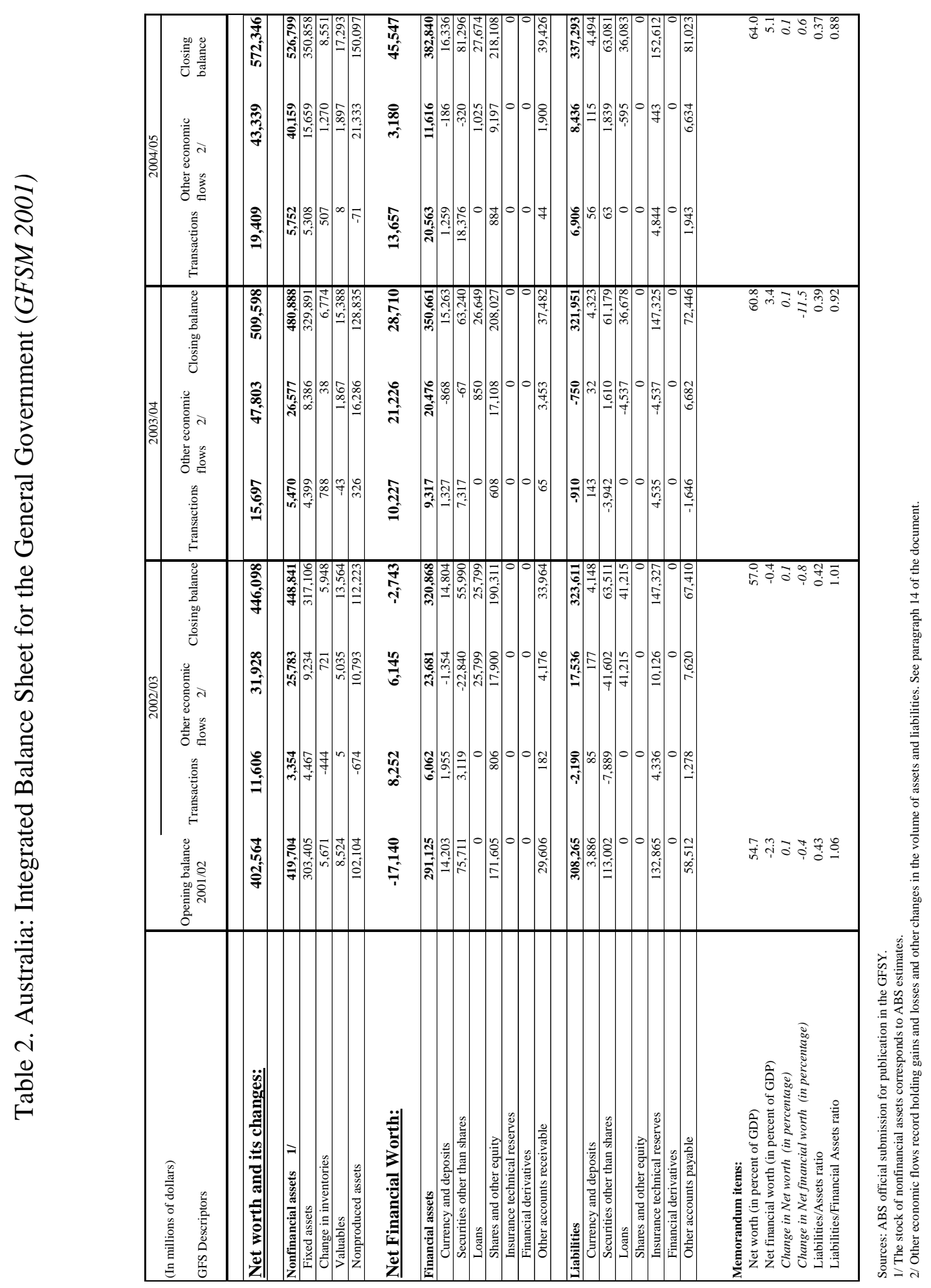




\section{Table 3. Australia: Statement of Sources and Uses of Cash for the General Government (GFSM 2001)}

(In millions of dollars)

\begin{tabular}{|c|c|c|c|c|c|c|c|}
\hline & GFSM 2001 Descriptors & 1999/00 & 2000/01 & 2001/02 & 2002/03 & 2003/04 & 2004/05 \\
\hline & \multicolumn{7}{|l|}{ Cash flows from operating activities: } \\
\hline 1 & Cash receipts from operating activities (inflows + ) & 238,354 & 252,283 & 260,445 & 284,567 & 307,273 & 332,365 \\
\hline 11 & Taxes & 194,442 & 208,412 & 214,633 & 234,742 & 253,318 & 272,026 \\
\hline 12 & Social contributions & 0 & 0 & 0 & 0 & 0 & 0 \\
\hline 13 & Grants & 303 & 490 & 964 & 1,507 & 1,043 & 1,399 \\
\hline 14 & Other receipts & 43,609 & 43,381 & 44,848 & 48,318 & 52,912 & 58,940 \\
\hline 2 & Cash payments for operating activities (outflows -) & $-210,653$ & $-232,244$ & $-242,593$ & $-258,187$ & $-276,532$ & $-294,438$ \\
\hline 21 & Compensation of employees $1 /$ & $-124,665$ & $-130,965$ & $-137,406$ & $-151,110$ & $-161,141$ & $-172,253$ \\
\hline 22 & Purchases of goods and services $1 /$ & $\ldots$ & $\ldots$ & $\ldots$ & $\ldots$ & $\ldots$ & $\ldots$ \\
\hline 24 & Interest & $-11,752$ & $-10,249$ & $-8,664$ & $-7,033$ & $-6,418$ & $-6,074$ \\
\hline 25 & Subsidies $2 /$ & & $\ldots$ & $\ldots$ & $\ldots$ & $\ldots$ & $\ldots$ \\
\hline 26 & Grants 2/ & $-21,182$ & $-27,483$ & $-29,051$ & $-31,196$ & $-32,915$ & $-34,734$ \\
\hline 27 & Social benefits $3 /$ & $-53,054$ & $-63,547$ & $-67,472$ & $-68,848$ & $-76,058$ & $-81,377$ \\
\hline \multirow[t]{3}{*}{28} & Other payments $3 /$ & $\ldots$ & $\ldots$ & $\ldots$ & $\ldots$ & $\ldots$ & $\ldots$ \\
\hline & Net cash inflow (+) from operating activities & 27,701 & 20,039 & 17,852 & 26,380 & 30,741 & 37,927 \\
\hline & \multicolumn{7}{|l|}{ Cash flows from investments in nonfinancial assets: } \\
\hline 31.1 & Purchases of nonfinancial assets (cash outflows -) & $-17,010$ & $-15,185$ & $-16,874$ & $-18,082$ & $-19,015$ & $-19,986$ \\
\hline 311 & Fixed assets & -16060 & -14359 & -16092 & -17204 & -17080 & $-18,557$ \\
\hline 312 & Strategic assets & 0 & 0 & 0 & 0 & 0 & 0 \\
\hline 313 & Valuables & -1 & -5 & -1 & -2 & -5 & -7 \\
\hline 314 & Nonproduced assets & -949 & -821 & -781 & -876 & -1930 & $-1,422$ \\
\hline 31.2 & Sales of nonfinancial assets (cash inflows + ) & 4,657 & 4,032 & 3,005 & 3,828 & 3,309 & 3,009 \\
\hline 311 & Fixed assets & 2308 & 1,579 & 2,035 & 2,271 & 1,961 & 1,595 \\
\hline 312 & Strategic assets & 0 & 0 & 0 & 0 & 0 & 0 \\
\hline 313 & Valuables & 0 & 0 & 1 & 0 & 3 & 0 \\
\hline \multirow[t]{13}{*}{314} & Nonproduced assets & 2349 & 2,453 & 969 & 1,557 & 1,345 & 1,414 \\
\hline & Net cash outflow (-) from investments in nonfinancial assets & $-12,353$ & $-11,153$ & $-13,869$ & $-14,254$ & $-15,706$ & $-16,977$ \\
\hline & CASH SURPLUS (+)/DEFICIT (-) $4 /$ & 15,348 & 8,886 & 3,983 & 12,126 & 15,035 & 20,950 \\
\hline & \multicolumn{7}{|l|}{ Cash flows from financing activities: } \\
\hline & Net acquisition of financial assets other than cash (cash outflows -) & $-1,391$ & $-3,659$ & $-5,297$ & 3,926 & 7,925 & 19,260 \\
\hline & Domestic & $\ldots$ & $\ldots$ & $\ldots$ & $\ldots$ & $\ldots$ & $\ldots$ \\
\hline & Foreign & $\ldots$ & $\ldots$ & $\ldots$ & $\ldots$ & $\ldots$ & $\ldots$ \\
\hline & $\begin{array}{l}\text { Net incurrence of liabilities (cash inflows }+ \text { ) } \\
\text { Domestic }\end{array}$ & $\begin{array}{r}-13,917 \\
\ldots\end{array}$ & $\begin{array}{r}-15,308 \\
\ldots\end{array}$ & $\begin{array}{r}-5,326 \\
\ldots\end{array}$ & $\begin{array}{r}-6,245 \\
\ldots\end{array}$ & $\begin{array}{r}-5,782 \\
\ldots\end{array}$ & $\begin{array}{r}-432 \\
\ldots\end{array}$ \\
\hline & Foreign & .. & $\ldots$ & $\ldots$ & $\ldots$ & $\ldots$ & $\ldots$ \\
\hline & Net cash inflow (+) from financing activities & $-12,526$ & $-11,649$ & -29 & $-10,171$ & $-13,707$ & $-19,692$ \\
\hline & NET CHANGE IN THE STOCK OF CASH & 2,822 & $-2,763$ & 3,954 & 1,955 & 1,328 & 1,258 \\
\hline & \multicolumn{7}{|l|}{ Memorandum: } \\
\hline & THE STOCK OF CASH (end of the fiscal year) 6/ & 12,743 & 9,727 & 14,203 & 14,804 & 15,263 & 16,336 \\
\hline
\end{tabular}

Sources: ABS official submission for publication in the GFSY.

1/ The Compensation for employees line (code 21) includes and Purchases of goods and services (code 22).

2/ The Grants line (code 26) includes Subsidies (code 25).

3/ The Social benefits line (code 27) includes Other payments (code 28).

4/ Net cash inflow from operating activities less the cash outflow from investments in nonfinancial assets.

5/ Cash surplus/deficit plus the net cash inflow from financing activities.

6/ Shown in the financial assets category "currency and deposits" in the balance sheet. Statistical discrepancies between the flows and the change of stock of cash are due to different data sources. These discrepancies are been investigated by the ABS. 